\title{
MODERNIZATION REFLECTED CREATIVELY: CENTRAL EUROPEAN CAPITALS IN THE MIRROR OF HORROR MOVIES
}

\author{
Alexander SAUTKIN ${ }^{*}$, Elena PHILIPPOVA ${ }^{2}$ \\ 1, 2 Murmansk Arctic State University, Social and Humanities Institute, Department of Philosophy and \\ Social Studies, 183720 Egorova ul. 15, Murmansk, Russia, Murmansk, Russia
}

Received 23 November 2017; accepted 08 June 2018

\begin{abstract}
The article deals with the creative interpretations of Central Europe by means of cinematography in the context of discussions about whether modernization means Westernization. The position is asserted that within Europe the ideal type of modernization is persistently associated with the West. The constructed in horror films images of Central European capitals are analyzed, with the example of such films as Short Night of Glass Dolls (La Corta notte delle bambole di vetro, 1971), The Spider Labyrinth (Il nido del ragno, 1988) and Hostel (2005). Prague (Chech Republic), Budapest (Hungary) and Bratislava (Slovakia), represented in these films, are marked with features of pseudo-modernity, which destroys the representatives of Western civilization or forces them to degenerate into monsters.
\end{abstract}

Keywords: Central European capitals, cinema, creative reflection, horror films, modernization, orientalization, stereotypes.

\section{Introduction. West versus East: the outlook direction}

The study of various social processes involves not only understanding corresponding reflexive practices (such as philosophical and scientific ones) that generate abstract theoretical models, but also analysis of the use of cultural codes and attitudes (in various situations), which allows us to reveal the real functioning of the creative thinking. In this article, we do not seek to generalize at the level that can be called "epistemic", in the spirit of Michel Foucault; our task is relatively small-scale - that is to describe some of the cases of creative reflection of the modernization processes in the field of cinematography, which, in our view, allows us to expand the set of initial data for analysis and to reveal the specificity of representational strategies generated by certain social conditions, as well as the force of their historical inertia.

Can the concept of "modernization" be regarded as a synonym for "Westernization" (or, at least, does the first concept include the second one as an element of its content)?

This is a question that has already become paradigmatic. The answers to it make a scale, where there are many other variants between the unequivocal "yes" and "no". For instance,

*Corresponding author. E-mail: sautkin72@mail.ru 
Anthony Giddens answers this way: 1) yes (in general), 2) no (in the context of the globalizing trends), 3) yes, with significant reservations (in terms of the development of reflexive knowledge). Ultimately, he writes that today:

"in the industrialized societies above all, but to some extent in the world as a whole, we have entered a period of high modernity, cut loose from its moorings in the reassurance of tradition and in what was for a long while an anchored 'vantage-point' (both for those on the 'inside' and for others) - the dominance of the West" (Giddens, 1996, p. 176).

Ronald Inglehart is more categorical:

"We reject the ethnocentric perspective of those who equated Modernization with 'Westernization': At one point in history, Modernization was concentrated in the West; today it is evident that the process is global, and that in some ways East Asia is now leading the process of Modernization. $<\ldots\rangle$ Although industrialization occurred first in the West, the rise of the West was only one version of Modernization" (1997, p. 11).

However, now we are talking about modernization processes in certain parts of Europe, and not all over the world. And we believe that in this situation the answer should be corrected: the modernization of Central and Eastern Europe may well be called "Westernization" if we recognize the last as the assimilation of social processes in the European periphery with the processes of its western "core". Actually, modernization, in the Weberian sense, is the unification of the European social space in the parameters of capitalist rationality.

Then again, what do we call a "periphery"? Prague was the capital of the Holy Roman Empire during certain periods of the Middle Ages. Budapest became the capital of the Kingdom of Hungary within the framework of the Austro-Hungarian Compromise of 1867 . Nevertheless, these glorious cities were the capitals of peripheral lands in the large empires (or in Austria-Hungary in the 19th century), and modernization for them rather meant following the imperial pattern.

Notable is the fact that the nationalistically oriented intelligentsia in many countries, in search for the foundations of national identity, appealed precisely to the rural way of life with its traditionalism, opposing to the corrupted city (and the capital city, first of all), since the city is the hostile agent of modernity. Of course, this opposition is a universal and widespread motive in European culture as a whole, but primarily for peripheral regions modernization and urbanization often meant dependence and submission, and local identity was sought for in the pre-modern rural life forms.

The modernization process acquired some specific features after the World War II. As noted by Róbert Takács,

“the Soviet Union was the model of modernization in 1950, and 'gave the definition' of development also in 1958. The West was narrowed into the position of an antithesis of the Soviet-style modernization as the example of an inhuman, empty, exploiting modernization that is to be transcended" (2014, p. 132).

The opinion of the Hungarian researcher is correct with certain reservations, since the 1956 uprising in Hungary, as well as similar ones in other countries of the socialist camp, demonstrated the disagreement of a large part of society with the Soviet model of socio-political 
development. However, due to the fact that those reformist movements failed, it was the Soviet model of modernization at the level of official ideology and policy that became dominant.

Of course, after the communist regimes' fall, the dominant idea was the "return to Europe", but the question, in fact, remains open: how does the "European core" (the West) perceive post-communist regions of Central Europe? And what does this return really mean?

Tomasz Zarycki in his book Ideologies of Eastness in Central and Eastern Europe (2014) examines in detail various narratives about Central Europe and presents an analysis of critical discourse, which, despite all the diversity of specific methodological approaches, interprets the post-communist Central Europe's attitude to the "core" as dependence and subordination of the hegemony of the West. ${ }^{1}$ Zarycki writes:

\begin{abstract}
"The structural dependence between the Western core and Central and Eastern Europe seems to produce a specific mode of cultural reductionism, which strongly influences the ways in which the dependence in question is later perceived and imagined. $<\ldots>$ This turns the discourse of the 'cultural roots of backwardness of the region' into a key narrative explaining its weakness in relation to the Western core" (2014, p. 43).
\end{abstract}

And then he points out:

"Old values, preserved in East European peripheries, and naïve but deep religiosity may be seen as fascinating but at the same time dangerous and horrifying because of their irrationalism and fundamentalism" (Zarycki, 2014, p. 44).

Here we can see a trend that can be called the "orientalization" of Central and Eastern Europe, in the sense given by Edward Said. It is a special type of discourse, expressing intentions of domination ${ }^{2}$. The reduction of the "backwardness" of these regions to the mentality, ethnic traditions and the greater archaic nature of these regional cultures reflects ideologically preset asymmetry in understanding the cultural features of the periphery in relation to the "core".

The belonging of the region to the West or to the East is likely determined by the point at which the one who makes the judgment is located. The West and the East are just the directions of the view, preceding possible movement (for example, a journey). A Russian, traveling to the Czech Republic or to Hungary, certainly goes to the West. A Frenchman heading for Poland unequivocally goes to the East. These "West" and "East" are somehow predetermined for the traveler by his culture's imagination. But staying in our place we cannot give an answer, who we are - the West or the East? There will always be someone more Eastern or more Western, but that is not the point, by and large. The point is rather that the Other's view is necessary for understanding oneself. We can see ourselves only through the eyes of the Other, as Mikhail Bakhtin once wrote.

\title{
1. Creating a city as a horror-film's setting
}

We would like to consider the work of the cultural and geographical imagination using the example of cinematic representations of Central Europe in several films related to the

\footnotetext{
${ }^{1}$ At the same time, Zarycki draws attention to the fact that the works of Western European authors (or those from Central and Eastern Europe, who are institutionalized in the West) are less dependent on anti-communist discourse dominating in post-socialist countries and, therefore, are more considered and critical.

2 "Orientalism as a Western style for dominating, restructuring, and having authority over the Orient" (Said, 1979, p. 3).
} 
"horror" genre. The cinematography is one of the most significant elements of the modern creative industry, therefore the study of creative strategies for understanding modernization processes by means of cinematography is very important. Why exactly horror-films? Probably, because it is this type of narrative that usually deals with the outlying and alien, invading everyday life, and if we recall Siegfried Kracauer, the genre reflects collective mental attitudes. As noted by Kyle William Bishop:

"horror and science fiction narratives are fundamentally well suited to explore cultural concerns of alienation and marginalization because of their ability to quite frankly and literally represent the Other as strange or alien" (2010, p. 99).

Having in mind the mentioned above "orientalization" of Central Europe, one could assume that the "otherness" of the Central European region in Western cinematic representations will be associated precisely with rural archaism, folk beliefs and the like. Such a non-Western Europe, of course, is present in the cinema. Here you can recall the classic films of Mario Bava The Mask of Satan (La maschera del demonio, 1960) and Black Sabbath ${ }^{3}$ (I tre volti della paura, 1963) (its second tale "The Wurdalak"). It is interesting that these films are claimed to be screen versions of the Russian classics. However, if "The Wurdalak" is clearly inspired by the story of Aleksey Konstantinovich Tolstoy, The Mask of Satan, depicting the struggle of the Inquisition of Moldavia (sic!) against witches and vampires, has little to do with the work of Nikolai Gogol. However, everyone knows that the homeland of vampires is Transylvania, therefore such films are unlikely to tell us anything significant: Central and Eastern Europe is, as a rule, very conditional here and serves a fairy-tale decoration to chilling stories of immortal bloodsuckers and other servants of Satan (not to mention numerous movie texts of Draculiana).

Especially it is worth mentioning Subspecies (1991-1998), the American (co-production with Romania) series of films about vampires, directed by Ted Nicolaou, where ethnographic elements of rural origin are closely intertwined with the urban realities of post-communist Bucharest. But in general, this tetralogy does not go beyond the traditional vampire discourse.

Therefore, we decided to review the films that feature the Central European capitals as such, namely: Prague, Budapest, and Bratislava. And here we find that the above-mentioned "cultural reduction" does not necessarily imply a referral to the traditional rural archaic.

The Russian semiotic Vladimir Toporov once introduced a notion of the "The Petersburg Text", or the "The Myth of Saint Petersburg" (1984). We believe that any significant city (especially the capital) also generates a text. There are whole cultural meta-texts about Prague, Warsaw (Poland) and Budapest, and the cinema plays an important role in this process. However, we will not consider the films of directors born in the countries of central Europe who represented their native capitals - this, of course, may be very productive, but now we are interested in the outside look - from the West.

Such central European capitals as Prague and Budapest are very intensively involved in the world cinematographic process: Western filmmakers often take films there. In a number of films, these cities themselves become the scene of action. We will not talk about Hollywood blockbusters like Mission: Impossible (1996) by Brian De Palma, Tinker Tailor Soldier

\footnotetext{
3 Also known as The Three Faces of Fear.
} 
Spy (2011) by Tomas Alfredson, and XXX (2002) by Rob Cohen, nor will we refer to films like Danish Prag (2006) by Ole Christian Madsen or Philip Kaufman's adaptation of the novel by Milan Kundera. For the analysis, we chose three horror films shot in the 1970s, 1980s, and 2000s respectively: Short Night of Glass Dolls, The Spider Labyrinth and Hostel.

The cities by their very essence are the centers of modernity, the centers of the ordering power of civilization, while the capitals are the focal points of power and energy, maximum possible within a given country. Therefore, it is embarrassing to discover archaic horror and irrational situations in the citadel of order and culture. However, this is what happens in horror films.

You can recall the ironic preamble to the Yugoslavian black comedy Strangler vs. Strangler (Davitelj protiv davitelja, 1984) by Slobodan Šijan (filmed in 1984), in which there is a reflection on what makes the city (the capital, in particular) a real metropolis. Not the great number of residents or heavy traffic, not a rich history at the meeting point of cultures, but a criminal chronicle, and the real metropolis must have its own maniac (as a strangler in Šijan's film). However, the fear caused by the maniac is something that is sensationally broadcast in the media, something that functions in the public field. The maniac is banal, being claimed by the image of a big city: the real capital not only means special perspectives that deny nature, not only roofs and crenellations, squares and corners, etc., but also the grotesque shadow of the creeping murderer on the wall - that is what Oswald Spengler forgot to include in his characteristics of the urban silhouette.

But the real horror is always private, it is not public, it lurks behind the thin veil of everyday life, revealing itself to just a few. We are not able to generalize it, but everything else is generalized by it. This plot move allows you to doubt the reliability of the ordinary course of things and the usual reality because of the sudden breakthrough of the irrational (that is, something that seems impossible, unthinkable in an urban environment). Rosemary's Baby (1968) by Roman Polański, David Lynch's Blue Velvet (1986), The Perfume of the Lady in Black (Il profumo della signora in nero, 1974) by Francesco Barilli, are all examples of the cinematographic narratives using this idea. Actually, the sensation of horror does not arise from the very appearance of the agents of evil, but from the fact that this appearance occurs in an irrelevant place: satanic rites in the center of New York; a severed human ear in the idyllic lawn of a small American town; sinister cannibal sect in the center of Rome.

In this sense, Central European capitals are special for that they seem to predispose to something fantastic and grotesque because of their geographical (and, probably, geopolitical) location. In the films in question, they appear as a kind of werewolf-capitals: their modernity does not have the usual Western foundations in the form of social rationality, the orderliness of norms, and the general predictability of people's behavior.

\section{Prague: a dead city for lifeless people}

Short Night of Glass Dolls by Aldo Lado was filmed in 1971 (co-production of Italy and West Germany).

The narrative structure of the film is unusual: the main action is given in a series of long flashbacks, which are memoirs of the main character, American journalist Gregory Moore, accredited in Prague. Moore is in a state of mysterious lethargy taken for death, and only 
his consciousness remains alive, making desperate efforts to restore to memory the previous events connected with the disappearance of his Czech fiancée. The off-screen voice directing the narrative is the voice of his consciousness, which is not able to convey to those around him that he is alive. The pseudo-dead body of the narrator is in the morgue, and the voice of his consciousness is not audible for anyone except the film viewers.

Prague, which is a scene of action, is completely devoid of tourist gloss in the visual aspect: it is gloomy, cold, gives a melancholy feeling, it is the realm of the dead in the guise of the living, and the living depicting the dead. One of the key metaphors of the film is a butterfly species, having no desire to fly despite their glittering wings and pretending to be dead all their lives. At the beginning of the film, the main character and his fiancée visit a social event where they meet representatives of the local political, economic and cultural elite, which appear as an exhibition of statues or a collection of living corpses. This motive will constantly arise in the future narrative during the film.

Peter Bondanella writes that Lado's apparent intention was "to reflect in some measure the frightening portrait of power found in the fiction of that city's greatest writer, Franz Kafka" (2009, p. 400). But does the film deal with power in general? On the one hand, such a broad interpretation is quite possible, although on the other hand, this film, shot three years after the Soviet troops' invasion in Czechoslovakia, certainly has a specific political background and is obviously tendentious. Actually, the genre of this film is a mixture of a thriller and an espionage film typical of the era of the Cold War. Journalist Moore is a kind of personification of the "open society", and this society is the West. The way he views his journalist profession is very indicative: the media for him is an instrument capable of changing the state of things in society, so he threatens the police commissioner by writing a revealing article about the investigation progress of his fiancée disappearance.

However, the location is the territory of the Other, and the usual schemes of the liberal-democratic modernity do not work here. Moore's friend, another Western journalist, tells him: "We are in a foreign country, and what surprises you may be happening here day by day; something that strikes a foreigner is the norm for the natives". The protagonist objects to her: "It seems that you are already on their side, and I'm showing myself, it is in my nature to resist while there is strength". He is not going to give up his searches, but in the end, he will have the worse, turning into a living corpse, conscious and perceiving, but powerless to change anything.

The main character's wanderings through Prague will lead him to a terrible discovery about the existence of some secret community that unites old people, who extract their vitality from the young. Young and full of strength, capable of free creativity people become victims of this power, - that is persistently accented by the director. In some cases, this idea is given point-blank: the authorities suck the blood out of society, either plunging it into senile impotence or destroying physically. People shown in the streets of Prague are old, emphatically ugly, depressed, with not a single smile on their faces, and those episodes are clearly highlighted by the author of the film: a particularly revealing is the episode showing for 40 seconds just passers-by moving past the famous chimes at the Town Hall in the direction of the Old Town Square. The plans of unpleasant old faces are mixed with images of gargoyles and mechanically moving figures on the striking clock. 
Phantasmagoric notes gradually increase, changing the genre of the film from a political thriller to a grotesque parable about the totalitarian gerontocracy, which deprives all living of their forces, natural feelings and the desire for flight. And this metaphor is clearly projected on the communist power in Czechoslovakia. The main character, in particular, says: "Their regime manages to survive only when it keeps a living person in a state of a dead".

\section{Budapest in the webs of fear}

Gianfranco Giagni's The Spider Labyrinth, filmed in 1988, describes a young American Professor's journey from Dallas (United States) to Budapest. The place of action could be any other, but the director, however, chose the capital of Hungary. The beginning of the film depicts Professor Alan Whitmore in America: crowded streets, streams of cars, sparkling skyscrapers in the background, the usual urban fuss. He goes to the office where he is offered to go to Budapest in order to find Professor Roth who participated in the international study of some ancient religious cult and found some significant artifacts, but then stopped contacting. The atmosphere of the film changes immediately after the main character moves to Budapest. The city is marked by several easily recognizable plans: the general plan of the bridge over the Danube, the Hungarian Parliament Building, etc. But the main action will unfold in desolate streets around the Buda Castle (we see the protagonist passing by the building of National Archives of Hungary): here are situated the hotel he lives in, the house of the Hungarian Professor, the antiquarian shop, which the American will seek long and unsuccessfully. Those streets become a real labyrinth for the protagonist, creating a surreal atmosphere akin to that of some paintings by Giorgio de Chirico and Paul Delvaux.

Throughout the film, the main character appears in a public place full of people only once - in some sort of cafe where he talks with Professor Roth's assistant. In all other episodes, we see him either in the desolate streets of Buda (often at night), or in dilapidated frightening interiors, or in some dark dungeons. Constant alarm build-up is achieved due to non-standard foreshortening (tilted camera, view from below and from above, etc.), as well as the sudden appearance of strange characters telling the protagonist to get away immediately to save his own life, and other "alienating" details (using the term of Viktor Shklovsky). For example, in a courtyard of Professor Roth's house, the main character meets a swinging boy dressed like people of the 1940s, while it is 1988 . This boy does not participate in the further development of the plot (we will once again catch a glimpse of him at the moment when the professor finds out about the suicide (or rather - the murder) of his Hungarian colleague), but he enhances the sense of strangeness and ominousness of what is happening. As Shklovsky wrote, alienation is "a way to see things taken away from their context" (1929, p. 17), which deprives us of the usual automaticity of perception and understanding. In fact, everything that happens to the main character in Budapest gives him the opportunity to see some terrible things, irrational and unthinkable in the daily Western order of life.

Some episodes are completely surreal in the visual sense, although there is no motif of mixing nightmares and reality: all the action takes place in reality, but this reality is alien to 
everyday life and makes a frightening impression. A person who has not been to Budapest should create a very strange idea of this city, in the back streets of which there dwell the spider-people, monstrous followers of a terrible cult. Characteristically, the protagonist says that scientists around the world worked on the research project that led him to Hungary, but only the researcher from Budapest discovered the terrible secret. "He learned that their gods are not a myth, but living beings", as one of the characters formulated. The film does not give a clue to the question whether there are followers of this sect in other countries, but we know for certain that the monsters feel at home in Budapest, and even the police inspector is among them. Moreover, an old man who helps the American Professor, says: "Today they have our city, and tomorrow the whole world". This prophecy is realized in the final scene, when Professor Whitmore, become one of the monsters himself, returns to America (in the last frames we see him on the background of the corpses torn by him).

The plot reminds some of the works of H. P. Lovecraft with his pantheon of terrifying ancient gods and their modern worshipers, although the film is not an adaptation of any of them. However, according to H. P. Lovecraft, the shelter of the dark forces is most often small settlements (Dunwich) and port towns (Innsmouth) or the Arkham (apparently having Providence as a prototype, which is the state capital, but clearly not a metropolis). But, in the film, the abode of monsters is one of the largest central European capitals, and it is from here that evil begins to spread around the world. The archaic cult lurks behind the facade of the millionth city, which in the cinematic narrative visually decreases to a maze of empty narrow streets with low-rise buildings.

This cult has no specific Central or Eastern European features, it is not rooted in the local rural archaism and the beliefs of native people; in fact, its essence and content are not specifically explained in the film. But from the whole research team, for some reason, only a Hungarian Professor managed to find out the truth, and it was in Budapest that the adepts of the sect organized their "spider's nest".

The "Other" is designed here as the embodiment of some hidden threat that is ready to spread all over the world, and the main character of the film, the American Professor, is not killed precisely because they want to use him: he is elected as the bearer of the "spider's seed" to return to America as an agent of the harmful influence. This motive is not articulated in political terms - The Spider Labyrinth, in contrast to Lado's film, rather, claims to be "pure art", "horror for the sake of horror". However, the "alien" in the form of a spider is implanted in the body of the protagonist not in Berlin (Germany) or in Vienna (Austria), but in Budapest, to cross the Atlantic Ocean and begin his bloody path in the New World.

A parallel with such a category of horror as zombie-movies is quite obvious here. In many studies, this category of films is considered in the context of post-colonial studies, and the figure of "zombie" is interpreted as the embodiment of colonized subjects that have escaped the control of former colonizers and threaten to destroy their world. In this sense especially revealing is the film by Lucio Fulci Zombie Flesh Eaters $(1979,1988)$ (aka Zombie 2 (1979) in the Italian box office). The plot is based on the journey of Americans to an alien region - an island lost in the Caribbean, from where a deadly zombie epidemic penetrates into New York. The structural similarity between Zombie 2 and The Spider Labyrinth is quite unambiguous. 
Some researchers regard the film of Fulci as a sample of the critique of the post-colonial syndrome in the former metropolises ${ }^{4}$, but Simone Brioni points out that, in his opinion, "Zombie 2 represents the fears of middle class Westerners concerning their privilege, which is threatened by the challenges of post-coloniality" (2013, p. 173), that "the representation of scary, exotically dangerous, contagious and partly human black subjects in Zombie 2 resurrects derogatory imagery, whose traces can also be found in some Italian literary works about Africa [in fact, there are the traces of classical colonial discourse - A. S.; E. Ph.]" (2013, p. 170). In our opinion, this position has the right to exist, taking into account the fundamental ideological ambiguity of the zombie-movies discourse.

Budapest in Giagni's film also appears as a certain terra incognita, which is fraught with danger, but this danger is not a strike back for the colonialists, because Hungary is not a former colony. It is rather what was hidden beyond the Iron Curtain, in the extremely Western part (if viewed from the East) of those territories that were covered by the influence of the Soviet Empire. One can recall that the film was shot a year before the fall of the Iron Curtain.

\section{Bratislava as "wild East": a story of the bad outskirts}

Of the three films analyzed by us, Hostel is probably the most famous among the mass audience. The across-Europe journey of an international group (two Americans and an Icelander) in search of pleasures ends in sadistic nightmares in Bratislava. (However, the film was shot not in the capital of Slovakia, but in Prague.) The movie, which integrated distinctive gore-cinema characteristics and the Hollywood mainstream, had a significant resonance in the research circles and began to be seen as a model of a "torture porn" movie - the name given in 2006 by David Edelstein in his famous article (2006).

In the context of our topic, one more work is remarkable - that is "The Subject of Torture: Regarding the Pain of Americans in Hostel" by Jason Middleton, in which he regards the Hostel as a projection of American geopolitical attitudes. Middleton presumes that "the film initially presents a critique of American aggression and cultural arrogance but ultimately justifies American violence in a manner resonant with the policies of the Bush administration" (Middleton, 2010, p. 1).

It is about the retribution performed by the only surviving character - Paxton - over his Bratislava torturers, at the end of the film. This, of course, may seem like an excuse for violence, however, in our opinion, the film should be perceived rather in an ironic way. To this, in particular, attention is drawn by Aaron M. Kerner, who writes:

"Hostel legitimizes Paxton's violence as the surviving protagonist, Middleton subsequently argues, 'and resonates with neoconservative perspectives on the justness and necessity of American aggression within a dangerous world'. <...> I would suggest that Roth

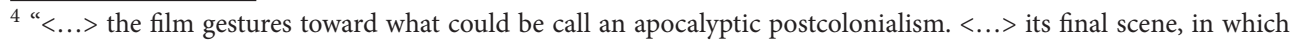
hordes of zombies enter New York City 'affirms in postcolonial fashion that the repressed history of colonialism $\langle\ldots\rangle$ has the potential to return with sufficient force to destroy all of Western culture, not just its far-flung outposts"' (Olney, 2017, p. 38). Also Agnieszka Soltysik Monnet writes: “Thus, the European zombie film [Zombie 2 - A. S.; E. Ph.], serving as a kind of political and historical conscience to the zombie genre, seems to insist that we see the destructiveness of the zombie as a white colonial infection that was brought to the Caribbean from Europe and activated, as it were, in the colonial encounter" (see 2015, pp. 149-150).
} 
views 'righteous vengeance' as tawdry, jingoistic, and morally bankrupt. $<\ldots>$ Unlike Middleton, I posit that the overwrought action/thriller genre conventions in the latter third of the film are more farce than an affirmation of a 'conservative vision of American violence as sometimes justifiable and necessary', as Middleton concludes” (2015, p. 110).

One of the producers of the film was Quentin Tarantino, known for the fact that his works are included in the powerful cinephile inter-text, and the director of Hostel Eli Roth fully shares the creative principles of Tarantino in this respect. Roth works with the exploitation-movie clichés in a completely postmodern manner: the story of how Americans taste Europe, that does not seem to like Americans too much, finds its end in the east of Europe. For where else could something like this happen, but not in the border zone between civilized and safe West (the story begins in Amsterdam) and quite "wild" outskirts, the space of the former Soviet Union? It is no coincidence that in Amsterdam a guy named Alexei suggests them in their search for sexual adventures to go to Ukraine (area of Odessa), and their reaction shows that it looks too extreme for them, so they prefer Bratislava, "a place where everything is possible to get for money". The guys enjoyed the carnal pleasures, though fleeting, their own flesh became the source of sadistic pleasure for others because the given formula has a universal character: "everything is possible for everyone".

Central Europe (although the characters move from Amsterdam namely to the "East") is the zone where the suppressed destructive desires of seemingly respectable western people find an opportunity to be realized. It is here that brutish violence takes the form of a service that can be obtained for money. "Wild East" which offers a price list of the relevant services is necessary to become a beast completely.

Violence in this area is represented as commonplace, and one of the most significant images, perhaps fully representing Bratislava, is a gang of young street children, who are ready to kill at any moment for a dollar or a bag of chewing gum. In the beginning, one of the American travelers named Josh almost becomes their victim, and at the end of the film the same gang helps Paxton to get away from the chase: the children brutally kill two armed and very brutal bandits for a package of sweets and chewing gum as a reward.

Hostel is an ironic terrible story about the unexplored and sinister outskirts of the global "world city", where decent people from "the center" (i.e. from the West) should not wander, and, unlike the two films discussed above, this story is served in a farcical manner, which is incidentally difficult to discern because of the abundance of bloody scenes of torture. Lado is extremely serious in his parable of the dead Prague, which only pretends to be a living modern city. While creating his own sterile horror, Giagni is also serious, not in moral or political messages, but in strict adherence to the canons of horror-movies. We will not find this seriousness in Roth's film, which cum grano salis deals with traditional stereotypes of perception of Central and Eastern Europe in the western mass consciousness. Bratislava (shot in Czech locations - in Český Krumlov and Prague), as well as Prague itself, are both extremely popular tourist destinations of post-communist Europe, but the region remains to be the focus of the archetypal fears of the modern West.

Notable is the fact that the film Hostel provoked a negative reaction of Slovak and Czech officials, who were outraged by showing their countries as savage and backward (BBC News, 2006). The commentary of the film director is important in this connection. Roth stated that: 
"Slovakia in the movie, it's not really Slovakia, it's movie Slovakia, and it's based on American stereotypes and these stereotypes, that the cars are old, the people are old, the telephones are old, these are the stereotypes that lure these guys into going there, they believe it and they pay for it" (Cameron, 2006).

The American and "core-European" stereotypes are very different, of course, but a certain similarity is still present.

\section{Conclusions}

The grotesqueness and deliberate unreality of horror films do not allow us to make universal and generalizing conclusions, as we can always refer to some more "respectable" film genres in which Central Europe is represented in a different way, but we can quite ascertain the presence of a specific trend in the image of the Central European capitals. The cinematography of horror, of course, does not represent social reality in its external forms, but it shows its deeper layers, its archetypes, attitudes, and images, functioning in the collective unconscious and in the mass consciousness.

Prague, Budapest, Bratislava - these cities are marked by all the exterior signs of modernity: large population, complex infrastructure, the outwardly rational organization of public interactions, after all, the same hostels, nightclubs and reckless parties with free mores of emancipated European youth. However, this is just a guise, a misleading appearance - like a shell with no nut inside it - hiding a certain pest that is much more unpleasant to meet than a worm in a bitten apple. (Not to mention "cinematic" Russia where almost anything is possible.)

Therefore, it can be assumed that the uneven development of the West-European "core" and the Central and Eastern European periphery is hitherto expressed in terms of the "delay in modernization" and "orientalization" of the periphery. This trend is not revealed at the level of official discourse, but, rather, shows itself ad marginem, in those everyday discursive practices dealing with obsolete, but nonetheless resistant stereotypes.

\section{Note}

The main points of the article were presented as a report during the international conference "Modern Capitals and Historical Peripheries", held at the Research Center for the Humanities (Institute of Philosophy, Hungarian Academy of Science, Budapest) on 20-21 October 2017.

\section{References}

BBC News. (2006). Slovakia angered by horror film. Retrieved from http://news.bbc.co.uk/2/hi/entertainment/4754744.stm

Bishop, K. W. (2010). American zombie gothic: the rise and fall (and rise) of the walking dead in popular culture. Jefferson, North Carolina and London: McFarland \& Company, Inc., Publishers.

Bondanella, P. (2009). A history of Italian cinema. New York, London: Continuum.

Brioni, S. (2013). Zombies and the post-colonial Italian unconscious. CINERGIE: Il cinema e le altre Arti, 4, 166-182. 
Cameron, R. (2006). Smash hit horror hostel causes a stir among citizens of sleepy Slovakia. Retrieved from http:// www.radio.cz/en/section/arts/smash-hit-horror-hostel-causes-a-stir-among-citizens-of-sleepy-slovakia

Edelstein, D. (2006). Now playing at your local multiplex: torture porn. Why has America gone nuts for blood, guts, and sadism?. New York. Retrieved from http://nymag.com/movies/features/15622/

Giddens, A. (1996). The consequences of modernity. Cambridge: Polity Press.

Inglehart, R. (1997). Modernization and postmodernization: cultural, economic, and political change in 43 societies. Princeton, New Jersey: Princeton University Press.

Kerner, A. M. (2015). Torture porn in the wake of 9/11: horror, exploitation, and the cinema of sensation. New Brunswick, New Jersey and London: Rutgers University Press.

Middleton, J. (2010). The subject of torture: regarding the pain of Americans in Hostel. Cinema Journal, 49(4), 1-24. https://doi.org/10.1353/cj.2010.0013

Olney, I. (2017). Zombie cinema. Series: Quick Takes: Movies \& Popular Culture. New Brunswick: Rutgers University Press.

Said, E. W. (1979). Orientalism. New York: Vintage Books.

Shklovsky, V. (1929). Iskusstvo kak priyom. In V. Shklovsky, O teorii prozy (pp. 7-23). Moskva: Federatsia.

Soltysik Monnet, A. (2015). The transnational zombie: postcolonial memory and rage in recent European horror film. In Ch. Decker \& A. Böger (Eds.), Transnational mediations: negotiating popular culture between Europe and the United States (pp. 143-159). Series: American Studies (A Monograph series). Heidelberg: Universitätsverlag Winter.

Takács, R. (2014). The vanishing Soviet Utopia in Hungary in the Light of de-Stalinization - Soviet Union as the Land of modernization in the Hungarian press, 1950-1958. Central European Papers, 2(1), 132-149.

Toporov, V. (1984). Peterburg i peterburgskiy tekst russkoy literatury. In Trudy po znakovym sistemam. Vol. 18 (pp. 4-29). Tartu: Tartu University Press.

Zarycki, T. (2014). Ideologies of Eastness in Central and Eastern Europe. Series: BASEES/Routledge Series on Russian and East European Studies. R. Sakwa (Series Ed.). Oxon and New York: Routledge. https://doi.org/10.4324/9781315819006

\title{
KŪRYBIŠKAI REFLEKTUOTA MODERNIZACIJA: VIDURIO EUROPOS SOSTINÉS SIAUBO FILMŲ VEIDRODYJE
}

\author{
Alexander SAUTKIN, Elena PHILIPPOVA
}

\section{Santrauka}

Straipsnyje nagrinëjamos kūrybinès Vidurio Europos interpretacijos, pasitelkiant kinematografijos priemones diskusijų, ar modernizacija reiškia vesternizaciją, kontekste. Tvirtinama, kad Europoje idealus modernizacijos tipas yra nuolat siejamas su Vakarais. Analizuojami siaubo filmuose konstruojami Vidurio Europos sostinių ịvaizdžiai, pasitelkiant tokius filmų pavyzdžius, kaip Trumpa stiklo lèliu naktis (La Corta notte delle bambole di vetro, 1971), Voro labirintas (Il nido del ragno, 1988) ir Nakvynés namai (Hostel, 2005). Šiuose filmuose vaizduojamus Prahą (Čekija), Budapeštą (Vengrija) ir Bratislavą (Slovakija) ženklina pseudomodernybės, griaunančios Vakarų civilizacijos reprezentantus arba priverčiančios juos išsigimti i pabaisas, bruožai.

Reikšminiai žodžiai: Vidurio Europos sostinès, kinas, kūrybinè refleksija, siaubo filmai, modernizacija, orientalizacija, stereotipai. 